\title{
Semiotic Study On The Elements Of Architectural Spaces In The Compound Of Istana Alwatzikhoebillah Sambas (Case Study: Istana Kesultanan Islam Sambas, Kalimantan Barat)
}

\author{
Alwin Fahreza ${ }^{1}$, Sudaryono ${ }^{1}$ \\ ${ }^{1}$ Architecture and Planning Department, Faculty of Engineering, Gadjah \\ Mada University, Yogyakarta
}

\author{
Article History \\ Received : 19 November 2018 \\ Accepted : 19 November 2018 \\ Published : 01 October 2018
}

\begin{abstract}
Semiotic approach in architecture aims to promote understanding and discussion on architectural works among people. In this research, the architectural works refer to signs in the form of architectural elements found in the compound of Istana Alwatzikhoebillah of The Sultanate of Sambas. The Sultanate of Sambas is an Islamic kingdom acknowledged since the 16th century. The present building of Istana Alwatzikhoebillah is the result of a renovation carried out in 1931, thus has been standing for 89 years. The objective of this research is to figure out the relationship between the signs situated in the architectural spaces around the compound of Istana Alwatzikhoebillah by employing Pierce's semiotic theory. This qualitative research uses rationalist paradigm with interview and observation as the data collection techniques. The collected data are analyzed using the diagram of Pierce's triadic model of sign, which consists of object, interpretant, and representamen. Through the finding, this research suggests the meaning represented by each element of the architectural spaces, which are Kalling Jembatan, Gerbang Segilapan, AlonAlon Istana, Tiang Kapal, and Gerbang Dalam Istan. Those five signs form a relational meaning which serves as a layered security architecture for Jalur Sulthan.
\end{abstract}

Keywords: Semiotics, Sign, Architectural Elements, Istana Alwatzikhoebillah, Sambas.

\section{Introduction}

In its development, semiotics is increasingly applied in the field of architecture in the postmodern architectural era, in which the work of an architect tends to be seen simply as a visual grandeur. At this point, architecture aims to promote understanding and discussion on architectural works among people. The term 'semiotics' is derived from a Greek word 'semion', which means 'sign' (Dharma, 2010:2). Aside from Chandler and Ferdinand de Saussure, Charles Sanders Pierce (18391914) is one of the thinkers who has a great contribution to semiotics. Pierce offers a triadic

Correspondence:Alwin Fahreza

Architecture and Planning Department, Faculty of

Engineering, Gajah Mada University, Yogyakarta

E-mail: alwinfahreza28@gmail.com diagram, which consists of referent, interpretant, and representamen, to comprehend semiotics. According to Broadbent, sign, as an object, is capable of conveying communicative information. It is able to stand for something else so that it can be perceived in someone's mind (Broadbent, 1980 in Dharma, 2010:2). Semiotics is considered a relevant study to assess the relationship between sign and meaning.

Semiotics is a scientific discipline which has gained recognition in many fields, one of which is architecture. The application of semiotics in such a field has been proven to be a method suitable for analyzing architectural works. Semiotic approach works to express an architectural form into a certain form in order to communicate the intended meaning. 
Semiotic Study On The Elements Of Architectural Spaces In The Compound Of Istana Alwatzikhoebillah Sambas Alwin Fahreza, Sudaryono
Architectural elements around a building or an architectural artwork bear a certain meaning which has been "affixed" by the "architect/designer". This is largely found in local architectural sites, such as the sultanate compounds in Indonesia, among which is the Istana Alwatzikhoebillah in Sambas, West Kalimantan. The name Alwatzikhoebillah consists of three Arabic syllables, which are Alwat (berhalwat), which means worship; zikhoe, which means "only Me"; and billah, which means "Allah SWT". Combined together, the full word means "I only worship Allah SWT" (interview with Fahmi, 2017). Such a name suggests a strong Islamic nuance as seen in each architectural element within the palace compound of the Sultanate of Sambas.

The spatial planning of such a palace compound during the heyday of the Sultan clearly implied a certain objective. The analysis of the meaning contained by the architectural elements in the palace becomes very important, as people's understanding on the meaning begins to fade. The development in tourism sector may also have some impacts on the architectural aspects, particularly with regards to the value and meaning of each architectural element, the evidence for the civilization of the Sultanate of Sambas.

\section{Research Objectives and Scope}

The research takes place in the compound of Istana Alwatzikhoebillah, which is located in the tip of Borneo, precisely in Sambas District, about 4-5 hours away from Pontianak, the capital of West Kalimantan. According to the history, the Sultanate of Sambas was formerly known as a large kingdom in the west coast of Kalimantan Island which dates back to the 16 th century AD. The Sultanate of Sambas had flourished since being governed by its first ruler, Sultan Muhammad Tsafiuddin I (1631-1668). The heyday of the Sultanate of Sambas brought renown to the land of Sambas up to the reign of the 15th Sultan, Sultan M. Mulia Ibrahim Tsafiuddin (1931-1943). During his government, the entire building of Istana Alwatzikhoebillah was renovated into the state which lasts to date. According to the chief of The Malay Cultural and Customary Council (MABM) Sambas, the design used for the renovation in 1933 was influenced by two elements of power prevailing during that period, namely the
Sultanate of Sambas and the Dutch East Indies (interview with Subhan, 2017).

Figure 1. The building of Istana Alwatzikhoebillah during the era of Sultan Muhammad Tsafiuddin II, around 18661922 (Source: Fahmi, 2018)

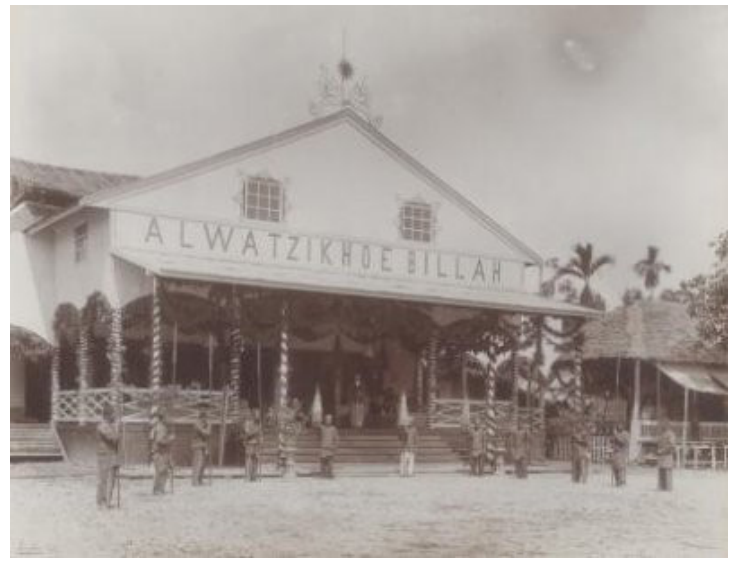

The objective of this research is to figure out the meaning represented by the signs in the form of architectural elements which are situated around the compound of Istana Alwatzikhoebillah, Sambas by employing semiotics approach. Each architectural element found in the compound constitutes the local wisdom is meaningful, especially to the royal family and the local community. The architectural elements classified as 'sign' in this research are Kalling Jembatan (Royal Dock), Gerbang Segilapan (Octagonal Gate), AlonAlon Istana (Palace Square), Masjid Jamik Istana (Jamik Mosque), Tiang Kapal Bendere (Ship Flagpole), Paseban (Waiting Hall), and Pintu Gerbang Dalam (Inner Gate). So far there is no written analysis that focuses on deciphering the meaning of the architectural elements constitute the compound of Istana Alwatzikhoebillah.

Figure 2. Current view of Istana Alwatzikhoebillah (Source: Researcher, 2018)

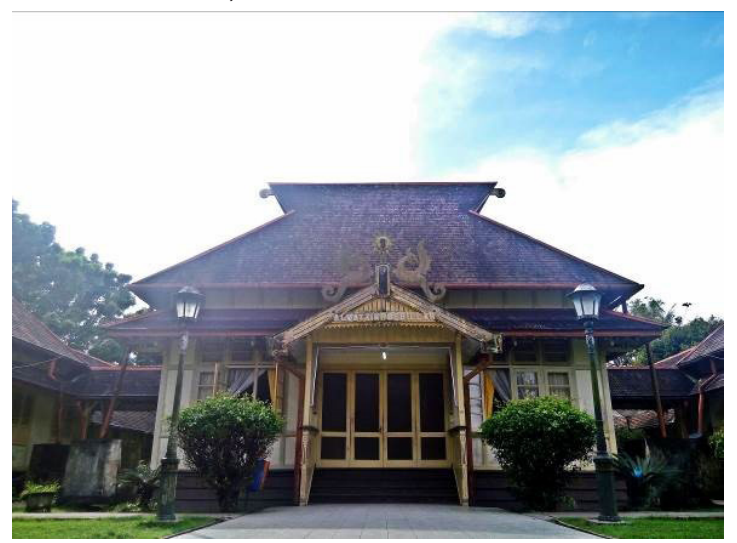


This research is expected to be the reference for the administrators and government of Sambas district in maintaining and developing the compound so such effort will not alter the meaning which has been found. The meaning of each architectural element becomes an important part in preserving the local wisdom. As for the contribution to knowledge, this research can be a model for the application of semiotics in architecture. In addition, this research also aims to promote understanding and discussion on the meaning of the architectural elements in Istana Alwatzikhoebillah among people, in general, and Sambas community, in particular.

\section{Review of Related Literatures}

\section{Semiotics}

Based on the history, the term semiotics was first introduced into the field of philosophy by John Lock in the late 17th century and later, around the 1930s, began to be more widely known. Charles Sanders Pierce (18391914), an American thinker, is one of the most influential figures in the development of semiotics.

Pierce points out the notion that "word" or "referent" is a form of sign; "object" is something referred to by the sign; and "interpretant" is the cognition on the sign about the object referred to by the sign in one's mind. To comprehend the sign system, Pierce introduced the Triadic diagram, which consists of three elements, namely representamen, interpretant, and referent. The three elements constitute a meaning in one's mind.

Pierce describes sign as a chain system which continues to develop along with the experience of each observer. Representamen is the physical form of a sign, which functions as its vehicle/medium; interpretant is the manifestation of the sign resulted from the relationship between the signs; and object is something referred to by such sign (referent). (Figure 3)

\section{Semiotics in Architecture}

Semiotics was first introduced to the field of semiotics in 1950 during an architectural debate meeting in Italy. At that event, there was a debate among the architects about the International Style. It was until the 1960s that France, England, and Germany started a
Figure 3. Pierce's Semiotic Triadic Diagram (Source: Chandler, 2007)

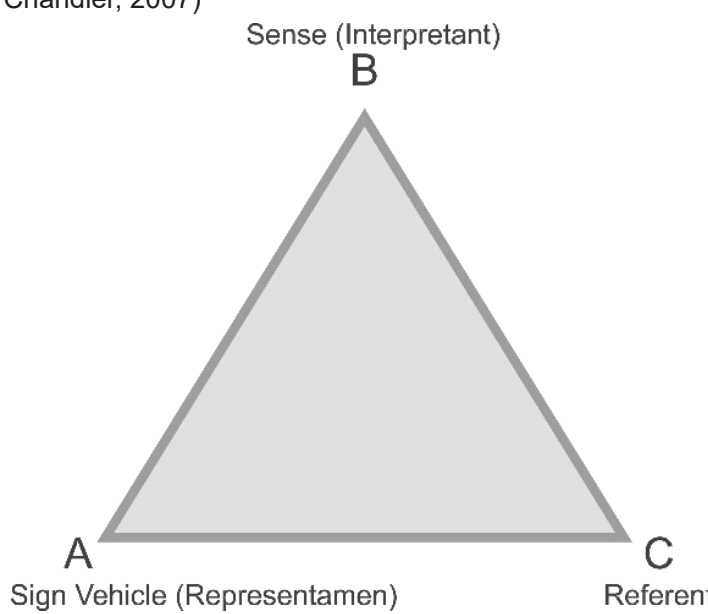

discussion on redefining the role of semiotics in architecture to refute normatively excessive functionalism theories. Understanding architecture as a medium or language to communicate ideas implies that a researcher is able to analyze architectural objects with linguistics as the basis.

Another thinker who brought semiotics into architecture was Umberto Eco. Eco describes architectural objects as sign system, in which architecture produces signs to bring about the visual representation of the function. Function is considered as the manifestation of the conceptual framework for the existence of the architectural objects. (Eco, 1986:77 in Ibrahim 2015:26). Eco explains the semiotic approach in architecture with reference to Pierce's theory. The signification of sign is an unstructured cognitive process, namely semiosis process. Thellefsen divided such a process into three grades, which are summarized in the grades of clarity diagram.

The first level is representamen, the "word", which by Zoest (1978) is classified into (1) Legisign (from the root word lex (law)), is the sign that becomes a sign because of a certain regularity that has been agreed upon. This type of sign is widely used in architecture, including in the structure system of a building. (2) Sinsign (sin: singular) is the sign which becomes a sign based on an event, form, or distinctive and original appearance. (3)Qualisign (quali: quality) is the sign which becomes a sign based on its quality/characteristics, e.g. red is chosen to be a color in the traffic signs for its striking characteristics. 
At the second level, namely object, Pierce introduces his trichotomy to distinguish three types of sign: (1) symbol, which is associated with the object arbitrarily; (2) icon, which is similar to or resembles the object; and (3) index, which is associated with the object physically. (Pierce in Eco, 2006:267-268)

At the third level, namely interpretant, the relationship between the sign and its interpretation is divided into (1) Rheme, which is a sign interpreted based on choice, e.g. the concept of a space; (2) Dicentisign or dicisign, a sign which is in line with reality/ facts, e.g. descriptive space; (3) Argument, a sign which provides direct reasoning based on logic or cultural perspective (Ibrahim, 2015:25). Thellefsen presents the relationship between the three grades of clarity in the grades of clarity circle diagram. This diagram is used in the analysis phase in order to present a comprehensible research finding based on the phases. The following is the circle diagram developed by Thellefsen based on Pierce's point.

Figure 4. Grades Of Clarity Model (Source: Thellefsen, 2000 in Ibrahim 2015:25) Interpretant (Level 3)

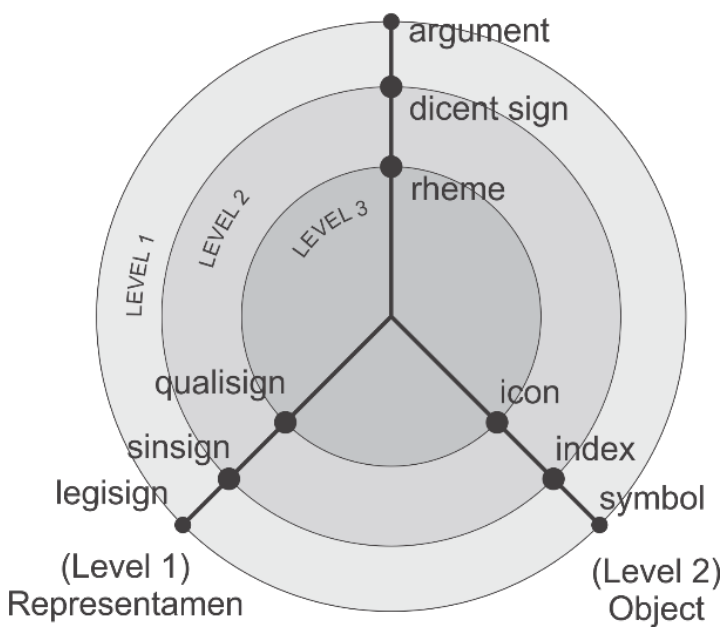

\section{Research Method}

This research relies on rationalism standpoint, through which the researcher sees the social reality based on the preexisting theories and synthesizes it with the empirical data/ the understanding of the research subject. Inductive-qualitative method is employed in this research with the focus on the substance of thought. The term 'inductive' implies that the reality at the field is examined to then be translated into meaning. The main theory employed in this process is Pierce's semiotic theory, which comprises representamen, object, and interpretant, as modeled by Theleffsen in grades of clarity circle diagram (Thellefsen, 2000 in Ibrahim 2015:25).

The researcher modified the sequence of the triadic processes into object, interpretant, and representamen, because this research uses inductive-qualitative method, which put field data as the basis for identifying the architectural elements around the palace compound as the object of the sign. The meaning of the object is confirmed by the analysis on the interpretant, which is obtained from the interviews and written documents about the relevant location, history, and folklore. The data obtained at interpretant level are then linked to the representamen, an interpretation from the researcher's analysis based on the scientific data or the applicable formality regarding the rules, characteristics, and nature. The analysis starts from the outermost circle to the middle circle and the innermost circle. Such sequence is based on the position of the qualisign indicator, which represents the quality of the understanding on a sign, thus is placed at the innermost circle. The following diagram presents the relationship between the three grades of clarity and the analysis sequence tailored to the purpose of this research. (Figure 5)

\section{Findings and Discussion}

The phenomenon that arises from a culture is a sign system containing meanings/messages in local language which is inherited from one generation to another, so that culture can be considered a system of communication. Culture is one of the forming elements in architecture which brings forth a meaning of a sign. The signs in this research are those located around the compound of Istana Alwatzikhoebillah, namely Kalling Jembatan, Gerbang Segilapan , Alon-Alon Istana , Masjid Jamik Istana, Tiang Kapal Bendere, Paseban , and Pintu Gerbang Dalam. The analysis method employs the grades of clarity circle diagram.

\section{Kalling Jembatan (Royal Dock)}

The palace compound is located by the estuary, suggesting the significance of river as the main transportation line. This is confirmed 


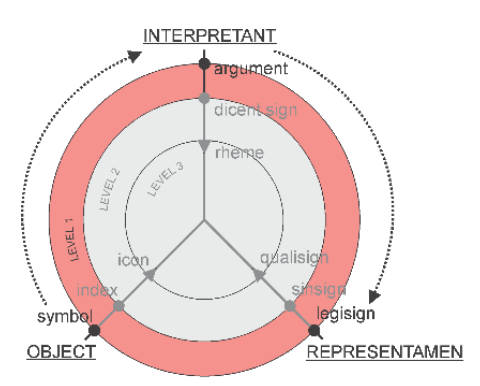

TAHAP 1

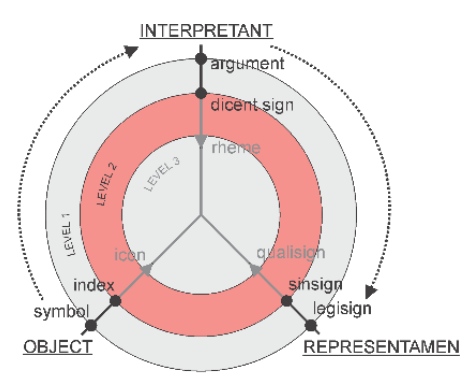

TAHAP 2

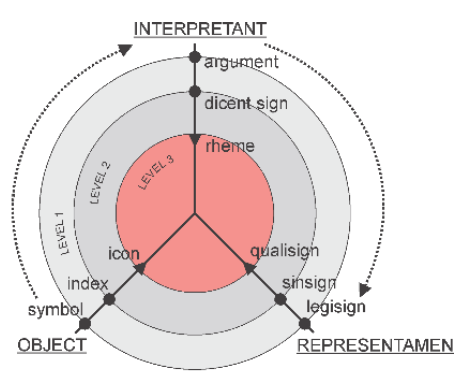

TAHAP 3 by the presence of the dock, which, in local language, is called Kalling Jembatan. This location was chosen by the second Sultan of Sambas, Raden Bima, whose title was Sultan Muhammad Tajuddin (1668 - 1708). He intended to build the capital at the confluence the three rivers, namely Sambas Kecil river from the west, Subah river from the south, and Teberau river from the north. This confluence is known as Muare Ulakan. The Kalling Jembatan has undergone a number of renovations for foundation strengthening, yet it still retains its original form and location.

Figure 6. Kalling Jembatan in 1920 (Source: Fahmi, 2018)

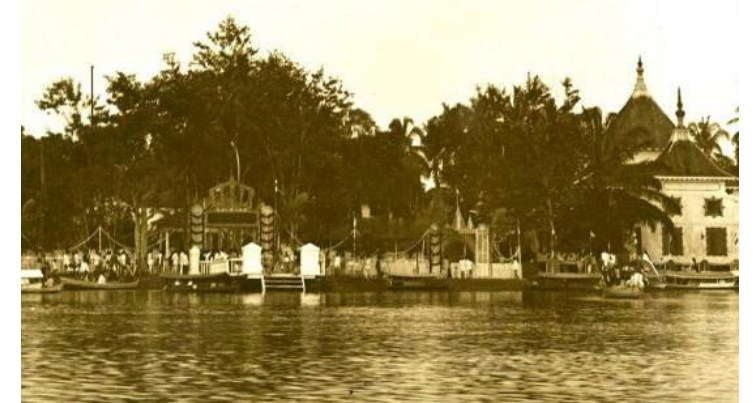

Based on the analysis on the first circle of meaning, Kalling Jembatan works as a symbol. It faces west as the direction of the flow of Sambas Kecil river. Such a state indicates that it is a place to welcome the sultan/guests whose ship docked there. In terms of argument, the only way for the sultan or his guests to access the palace is Sambas Kecil river, which flows to Sambas Besar and Pemangkat Rivers (interview with Fahmi, 2018). Aside from its role as the main access to the palace, Sambas Kecil river is also connected to South China Sea/Karimata Strait. In terms of legisign, those allowed to dock at Kalling Jembatan are exclusively the Sultan, the royal family, the palace guards, (Tan), and the royal guests.

Figure 7. The Welcoming of the Royal Guest from Netherland in 1920 (Source: Fahmi, 2018)

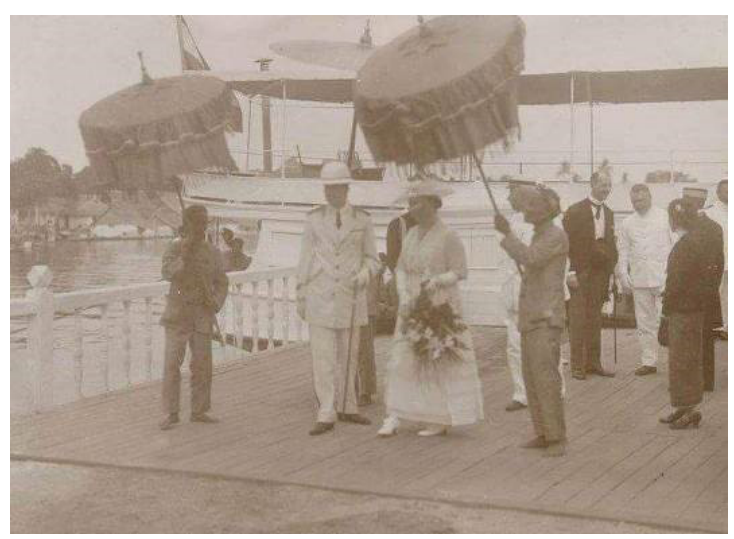

In the second circle of meaning, Kalling Jembatan also works as an index. Just like the other docks, it is located by the river/estuary and functions as berth for vessels like boats, ships, or speedboats. According to Fahmi, Kalling Jembatan still retains its original form, color, and function. The only thing that changed is its size; it gets smaller from time to time (interview with Fahmi, 2018). In terms of dicentisign, it is explained that the only difference between the present and past docks is the user. Back then it was an exclusive facility for the sultan and the guests. Now it is functioned as a public facility. In terms of sinsingular/sinsign, Kalling Jembatan is colored in yellow to signal caution and grab the attention of those who might see it. This idea is in line with the Law of the Republic of Indonesia, article 59 paragraph 1 , which underlines the function of yellow to signal caution. The combination of yellow and dark green stripe on the exterior of Kalling Jembatan works to issue caution and provide high visibility. (Figure 8) 
Figure 8. Kalling Jembatan in present days (Source: Researcher, 2017)

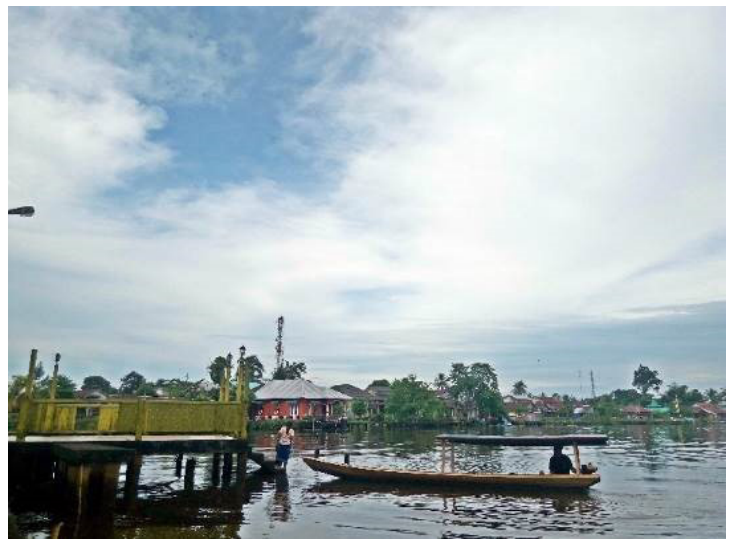

At the third layer of meaning, as an icon, the characteristics of Kalling Jembatan are similar to those of common docks. A dock is an access available for any means of water transportation. The presence of Kalling Jembatan indicates that water transportation is important for the sultanate. In terms of rheme, Kalling Jembatan was initially dedicated to sultan/special guests (interview with Fahmi, 2018). As time elapses, the purpose changes and it is turned now into a public facility. In terms of qualisign, Kalling Jembatan serves an important purpose as the place for sultan's departure and arrival and for holding an important event, such as welcoming ceremony for the guests from the neighboring kingdom. The yellow color of Kalling Jembatan symbolizes glory (Akhminanti, 2013:92), with the sense of glorifying everyone who came into and left the palace.

Figure 9. The Circle of Meaning in Kalling Jembatan (Source: Researcher, 2018)

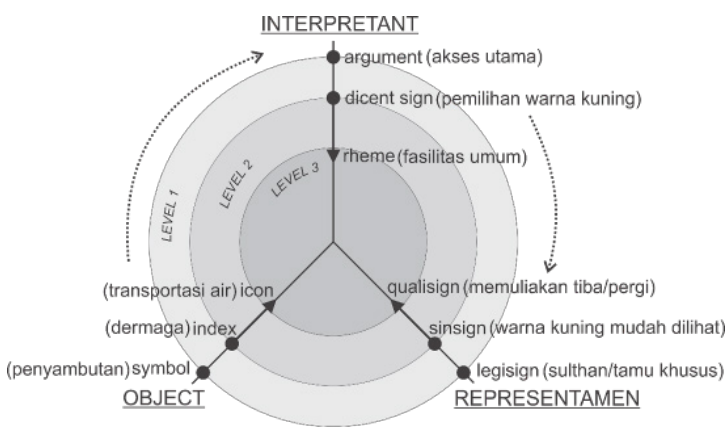

\section{Gerbang Segilapan}

As a keep for the sultan, the palace needs a strong defense, thus barrier, in the form of fence, is needed. Aside from security purpose, the fence also functions as the border for the sultanate's territory. Based on the sequence of the entry line, Gerbang Segilapan is situated right after the Kalling Jembatan. It is 10 meters in height and divided into two floors. The first floor is in octagonal shape with an open wall, while the second floor is rectangular, with a pyramid and pointed roof. Gerbang Segilapan is dominated by yellow and white.

Figure 10. The front view (left) and rear view (right) of the Gerbang Segilapan (Octagonal Gate) (Source: Researcher, 2017)

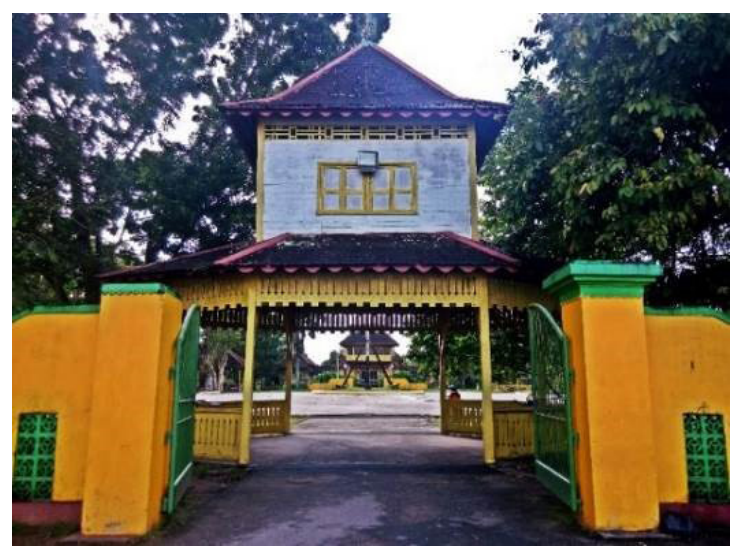

On the first circle of meaning, Gerbang Segilapan works a symbol which represents the security of the palace since this gate is the outermost layer of the palace compound. In terms of argument, the sultan or the guests paying a visit to the palace passed the gate with the escort of the palace guards. It is confirmed by Fahmi, who stated that the sultan/ special guests would be accompanied by the guards to get through the Gerbang Segilapan after they arrived at Kalling Jembatan. The guards are known to be from the Tan clan (interview with Fahmi, 2018). According to The Great Dictionary of Indonesian Language, gate (gerbang) is an access through which the family enters the house. It can be a field, town, and so on (KBBI Online, 2018). Based on that reference, in terms of legisign the gate serves as the entry/exit point which accommodates any activities that connects cities, fields, or between the inner and outer zones. (Figure 11)

In the second circle of meaning, as an index, the gate indicates two territories which were interconnected, thus an access that connects the two zones was necessary to enable easier surveillance over the inwards and outwards activities. Fahmi pointed out that the gate was previously dedicated to sultan, his guests, and 
Figure 11. The interpretation on the points of the compass as shown by Gerbang Segilapan (Source: Google with a modification by the researcher, 2018)

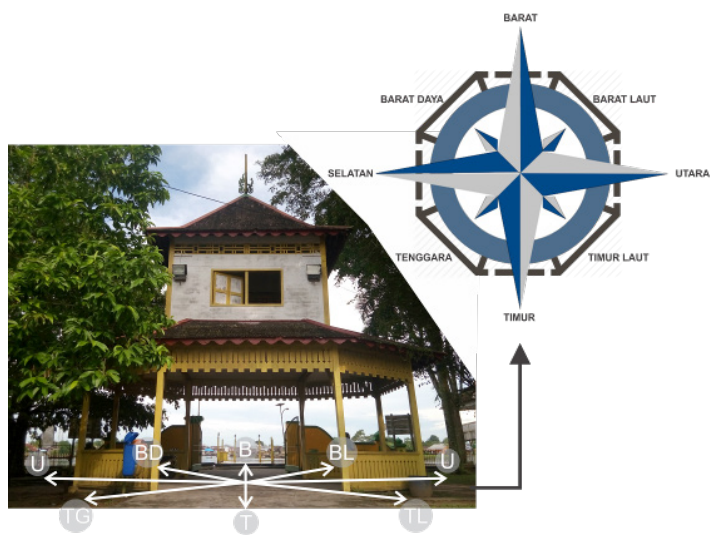

the sultanate apparatus, but now it is open to the public to show the interaction between the sultan and his people (interview with Fahmi, 2018). That point suggests that the dicentsign conveyed by the gate is the connector between the sultan and his people. Gerbang Segilapan consists of two floors and the sinsign is shown by the first floor, which is a combination of Malay and Chinese architectural style. The Malay style is reflected by the columns of the stage, while the Chinese style can be seen from the cross-sections of an octagon on the bottom floor, which suggests a strong nuance of Confucian style. The second floor is more likely a confined space and an empty room without stairs nor any other access to it. According to the story passed down through generations in the royal family, this room is the place for the mythical guards to support the surveillance.

In the third circle of meaning, this gate also works as an icon. The octagonal shape of the gate represents the eight points of compass. In his confirmation, Fahmi also stated the diagonal cross-sections of Gerbang Segilapan forms an octagon, symbolizing 8 guards who would welcome and protect the sultan or his guests at eight points (interview with Fahmi, 2018). As for the rheme, the eight points at the gate indicates 8 palace guards placed on each corner. However, in present days the 8-guard formation is set only at the event of sacred and cultural ceremony to commemorate a certain event as a form of cultural preservation. In terms of qualisign, the gate of Gerbang Segilapan is dominated by yellow and white, the bright colors that might stimulate the guards/gate guardians to be more watchful. It is because white and yellow can stimulate the cognitive activity to support logical and analytical reasoning.

Figure 12. The Circle of Meaning in Gerbang Segilapan (Source: Researcher, 2018)

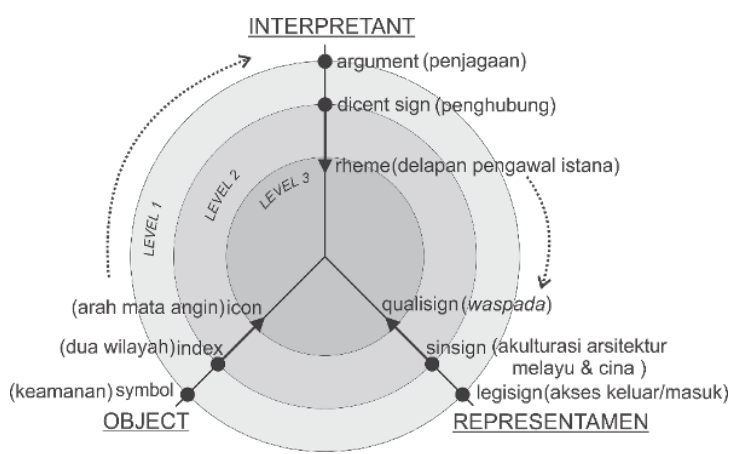

\section{Alon-Alon Istana}

After Gerbang Segilapan, there is a $50 \times 50 m$ field, called alon-alon in local language, with the area of about $2500 \mathrm{~m} 2$. It was also explained by Fahmi that the field was renovated by Sultan Muhammad Tsafiuddin II, the thirteenth sultan of Sambas, in the end of 18th century and converted into a plaza, or alon-alon in local language. Back then, this square was used as the muster point for the guards before going to the battlefield. This square also functions as a place for welcoming ceremony, pencak silat training, and night market/people's entertainment. These activities serve as a form of interaction between the sultan and his people, in the effort to bring about welfare and prosperity.

Figure 13. Present condition of the Alon-Alon (palace square) of Istana Alwatzikhoebillah (Source: Researcher, 2018)

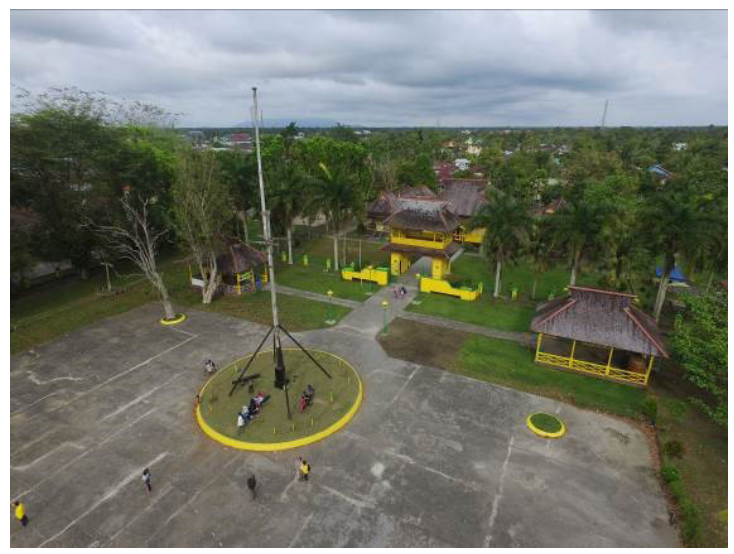

On the first circle of meaning, the palace square works as a symbol which represents the center of the city or the government. Based on Fahmi's explanation, at that time the sultan commemorated feast days by hosting 
Semiotic Study On The Elements Of Architectural Spaces In The Compound Of Istana Alwatzikhoebillah Sambas Alwin Fahreza, Sudaryono parties or entertainment events for his people in this alon-alon. The entertainment events include night market, dance performance, and puppet show (interview with Fahmi, 2018). From that explanation, the argument can be derived. Alon-alon is functioned as a point for community gathering for it is a vast open space. As for legisign, refering to The Great Dictionary of Indonesian Language, alon-alon is a vast open field located in front of a palace, or the residence of a king/sultan, regent, and so on (KBBI Online, 2018). One characteristic of the center of a town or government, either for a sultanate or a district, is a vast grassy field and a pair of banyan threes located at the middle of it (Warpani, 2011:1). In the context of this locus, the palace square of Istana Alwatzikhoebillah have two banyan trees that have a historical value, namely the white banyan trees. The seedlings of the white trees (Malaleuca Leucadendron) are the gifts from the chief of Dayak tribe to symbolize peace between Dayak and Melayu. Up to now, the trees still stand strong. This was also to commemorate the War of Sungkung in 1883. The seedlings were planted by Commander Daud and Commander Bakar by the order of the sultan (Rahman, 2001:82).

Figure 14. The Zoning at the Palace Square (Source: Researcher, 2018)

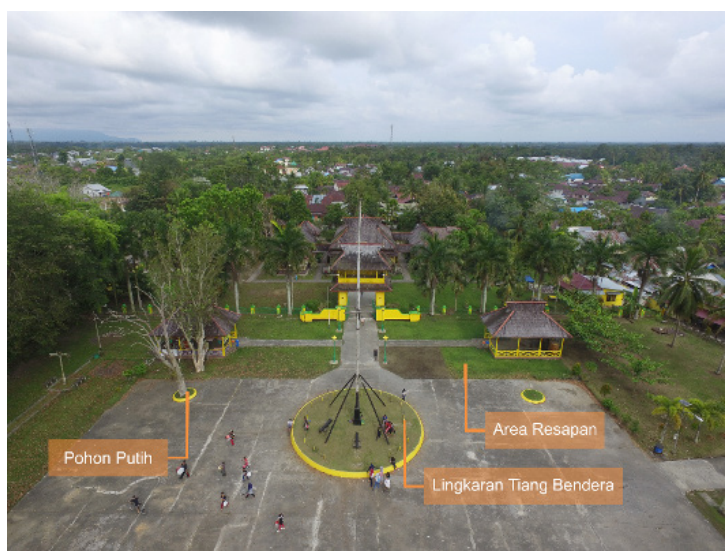

In the second circle of meaning, there are several elements that constitute the characteristics of an alon-alon. The elements are interconnected to form the meaning as an index. Among the elements is the green circular platform which functions as the base for the flagpole and is located at the middle of the east side. On the northeastern, stand firm the two white trees. All other elements in the palace square unite with the characteristics of vast field and shade trees. Fahmi pointed out that back then in the era of Muhammad Tsafiuddin, the square was smaller than present days since the palace buildings was bigger (interview with Fahmi, 2018). During that era, the alon-alon area consisted of concrete pavement area $(75 \%)$ and infiltration area (25\%). That explanation indicates the dicentsign of the alon-alon of Istana Alwatzikhoebillah. It has a square shape with the area of $50 \times 50 \mathrm{~m}$, paved with concrete, and encircled by the green infiltration area.

Figure 15. The size the Alun-Alun (palace square) of Istana Alwatzikhoebillah (Source: Researcher, 2018)

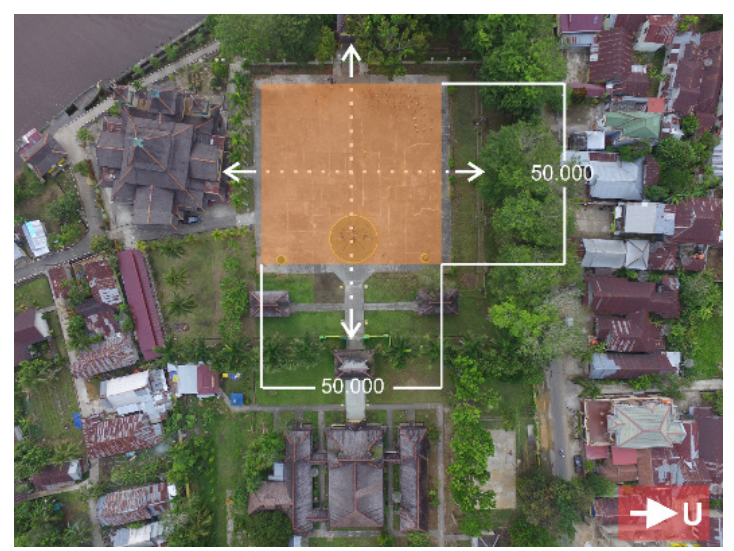

In the past, the variety of the public open spaces was naturally constructed by the surrounding buildings. Some figures in architecture offers some classifications of the public open spaces in the world. Rob Krier classifies the shapes public open spaces into rectangular, cluster, square, orthogonal, geometric, circular, triangular, and angled, while Spiro Kostof classifies it into circular, square, trapezoid, letter L, triangular, and irregular (Krier, 1938 in Putra, 2015:3). Based on the functions, in terms of sinsign, the alon-alon is a public open space constructed as a result of the spatial design of the palace compound.

As pointed out by Mardiono, basically the concept of alon-alon is originated from Javanese civilization. Commonly one can be found around the residence of a ruler. It also symbolizes the concept of deity. The banyan trees in the middle of it symbolize life that grows amid an empty space. The concept of a great palace facing the oceans, equipped with a big dock, and with mountains on its back symbolizes prosperity. All those states construct the third circle of meaning of AlonAlon Istana (Mardiono, 2009 in Warpani, 2011:1). Drawn back to the research locus, the Istana Alwatzikhoebillah works as an icon with 
its large yard in front of the house of the cultural ruler/leader of Sambas, namely the residence of the sultan, the sultana, and the prince.

The rheme in Alon-Alon Istana refers to the spatial concept of the Javanese royal compound. This is confirmed by Fahmi, who stated that during the era of Sultan Muhammad Tsafiuddin II, alon-alon is the front yard of the sultan's house. This concept started to be applied in the era of Sultan Muhammad Mulia Ibrahim who once studied in Cianjur, West Java (interview with Fahmi, 2018). The sultan expanded the front yard and turned it into a plaza by referring to the spatial concept of the Javanese palace. As pointed out by Handinoto, alon-alon is a concept of public open space popular among Javanese people. The spatial concept which incorporates an alon-alon as a part of the royal compound/center of government had been known since the 13th-18th century, particularly during the heyday of Majapahit kingdom up to the era of Mataram Kingdom (Handinoto, 1992 in Indrianingrum, 2015:17). The change in the layout of the palace was influenced by Sulthan Muhammad Mulia Ibrahim, who reigned in 1933. In his childhood, he was sent by his parent (Sulthan Muhammad Tsafiuddin II) to Cianjur, West Java, to study and was educated well by the Dutch to be the heir of the sultanate. The knowledge he gained during his stay in West Java influenced the policies out during his era in Sambas, especially in terms of the construction and the structuring of the palace space, one of which was the alon-alon.

The unique characteristic of the alon-alon of Istana Alwatzikhoebillah indirectly makes it the landmark of Sambas city, which at the same time indicates qualisign. Landmark is a visually attractive site placed at an attention-grabbing spot. Commonly a landmark has a unique shape, while the size varies between each other depending on the surrounding area (Lynch in Susilohadi, 2014:12). Up to now, the alonalon of the palace still serves its function as a gathering spot for various purposes, such as evens, educational activities, and recreations. In the morning and afternoon, this place is crowded by domestic and foreign tourists. Alon-alon becomes the subject of concern for it is situated inside the compound of Istana Alwatzikhoebillah and has a wider area than the surrounding objects so it can accommodate the events held for the local people and visitors.
Figure 16. The Circle of Meaning in Alon-Alon of Istana Alwatzikhoebillah (Source: Researcher, 2018)

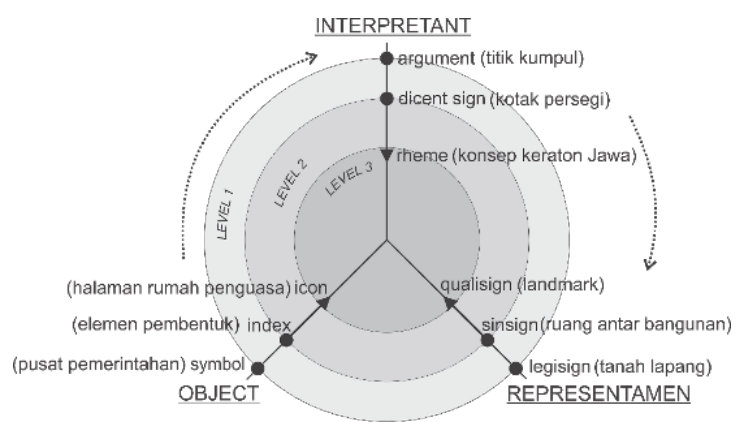

\section{Tiang Kapal Bendere}

Upon entering the alon-alon area, a flagpole that looks like a ship mast will come into sight. This flagpole is called Tiang Kapal. It stands on the east side of the alon-alon surrounded by three canons. The canons are still functioning. These are the relics from the British colonizers, who stayed from 1812-1813. According to the history, the wooden flagpole was taken from one of the warship owned by the Sultanate of Sambas during the era of Commander Anum, one of the heirs of the sultanate. This flagpole is made of rasak padi wood taken from Mountain Senujuh by a palace guard named Tan Terabbik. This mountain is $25 \mathrm{~km}$ northeast of the palace.

Figure 17. The position of the Flagpole in Istana Alwatzikhoebillah (Source: Researcher, 2018)

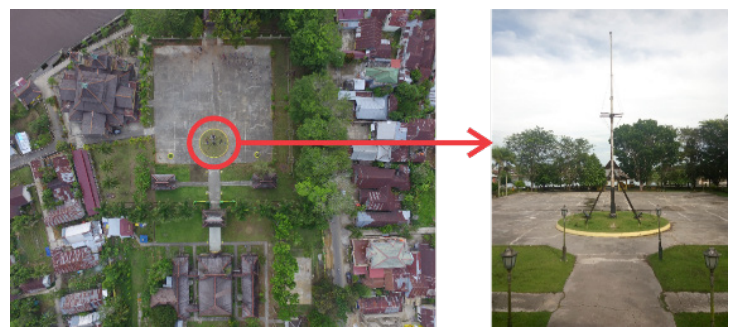

Based on the analysis on the first circle of meaning, this flagpole works as a symbol which represents power over a territory. According to Fahmi, before the independence of Indonesia, the color of the flag was plain yellow and raised to signify the messages from the sultan (interview with Fahmi, 2018). That explanation indicates the argument carried by the flagpole, i.e. it is raised to deliver messages. When the yellow flag is raised until the top point of the pole, war is about to take place. The yellow flag which is raised half-mast announces the obituary from the royal family. In terms of legisign, the presence of flagpole in a location indicates the existence of institutional power over a territory 
or the location of the center of government. Commonly a flagpole is positioned at an open field and linear with the main building (Santoso, 2008:151).

In the second circle of meaning, the flagpole works as an index, which is closely related to the characteristics of the Sultanate of Sambas as a maritime country with its strong navy. The flagpole was taken from the Prince Anum's ship, one of the Commanders in charge of the naval fleet of the Sultanate of Sambas. In terms of dicentsign, the flagpole was taken from a historic vessel with the hope that the future generations will always remember the struggles of their ancestors and the glory of the Sultanate of Sambas on the water. This pole also functions as communicator, e.g. to deliver the message of war. Such a function is also found in the Tiang Kapal Bendere. According to Fahmi, this flagpole functioned to deliver the message from the sultan to the people about various events taking place at the area of the Sultanate of Sambas, such as war, death, or royal ceremony (interview with Fahmi, 2018). Nowadays, this flagpole only functions to raise the flag in the ceremonies. As for the color, $3 / 4$ portion of the upper part of the pole is colored in white, while the rest $1 / 4$ of the lower part is in black. In terms of sinsign, the combination of such colors serves well for camouflage in a misty weather on the sea, so that the ship can escape the enemy's attention. In a number of literatures, black gives the impressions of dark, gloomy, and frightening, while white might trigger headache and eyestrain.

Figure 18. The Parts of the Flagpole of Istana Alwatzikhoebillah (Source: Researcher, 2018)
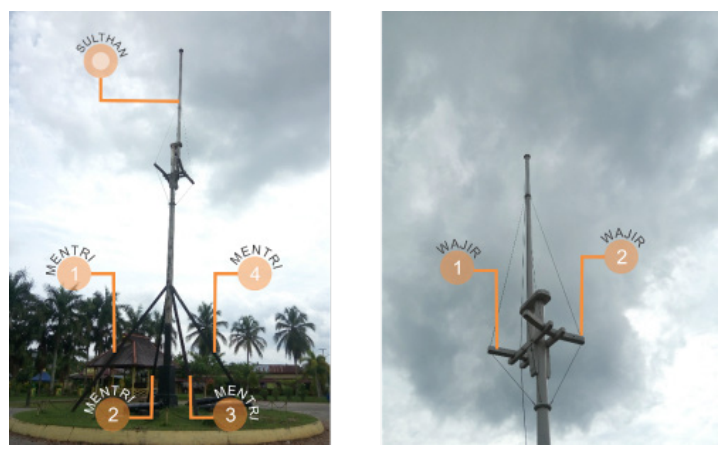

In the third circle of meaning, the flagpole also works as an icon since its structure resembles that of the ship mast. It is also confirmed by Fahmi, who stated that this flagpole was taken from a vessel owned by Captain Anum, namely
Kerius Ship. This flagpole is made of rasak padi wood taken from Mountain Senujuh. It was retrieved by a palace guard named Tan Terabbik. In terms of rheme, the concept of the flagpole indicates its function as a work instrument for the Sultanate of Sambas. Structure wise, the flagpole consists of several parts, namely the vertical main pole, two horizontal wooden slats at the top tied with the strap of the ship screen. The concept of work instrument in the flagpole is reflected from the 4 diagonal supports which represent the 4 royal servants, which are called menteri citre. The names of royal servants are Pangeran Laksamana, Pangeran Pakunegara, Pangeran Amar Diraja, Pangeran Cakranegara. At the top of the pole, there are 2 horizontal bars, which represent 2 viziers of the sultan, namely Pangeran Bendahara dan Temanggung Kusumanegara. In terms of qualisign, the flagpole symbolizes the persistent struggle demonstrated by the sultan, viziers, and menteri citre to protect the unity of the Sultanate of Sambas. Such a unity is reflected by the flagpole which was taken from the ship of Prince Anum and gives the proof for the glory of the Sultanate of Sambas.

Figure 19. The Circle of Meaning in Tiang Kapal Bendere Researcher, 2018)

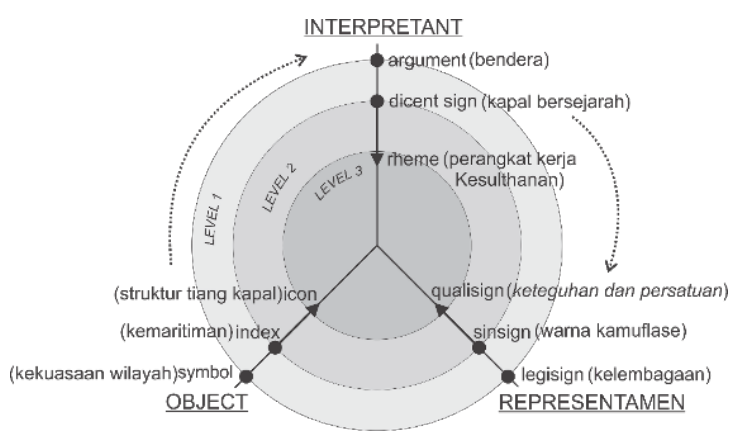

\section{Gerbang Dalam Istana}

After passing the Paseban, the next element of sign is Gerbang Dalam Istana (the Inner Gate of the Palace). This is the second layer of protection which divides alon-alon and the sultan's house. This gate was build at the same time as the sultanate royal house in 1933 by Sultan Muhammad Mulia Ibrahim Tsafiuddin. In the first circle of meaning, Gerbang Dalam Istana works as a symbol as a partition between the sultan and the guests/people. It is confirmed by Fahmi, who stated that Gerbang Dalam, serves as the second layer of protection for the sultan's house. Not everyone is allowed to pass or enter this gate (interview 
with Fahmi, 2018). Only those who are invited by the sultan/have the privilege may pass or enter and meet the sultan. The upper floor is used by the sultan and the royal family to spend their leisure while observing the activities around the palace. From that explanation, the inner gate of the palace indicates meaning as an argument, i.e. the relationship between the social status and the right to enter a certain part of the palace. Tha apparatus of the sultanate reserve the right to inter the sultanate palace, while common people might only enter the alon-alon and mosque. In terms of legisign, this gate shows the second layer of protection for the compound of Istana Alwatzikhoebillah. This is symbolized by the two gates and two layered fence surrounding the palace. Security is something crucial, particularly to ensure the safety of the sultan as a leader. In terms of access, one of the differences between the two gates is about the upper floor. The upper floor of the inner gate is accessible by the stairs located at the northern part of the gate, while that of the other gate (the octagonal gate) cannot be accessed; only the bottom floor is accessible as it functions as the entry/exit point.

Figure 20. Gerbang Dalam Istana (Source: Researcher, 2018)

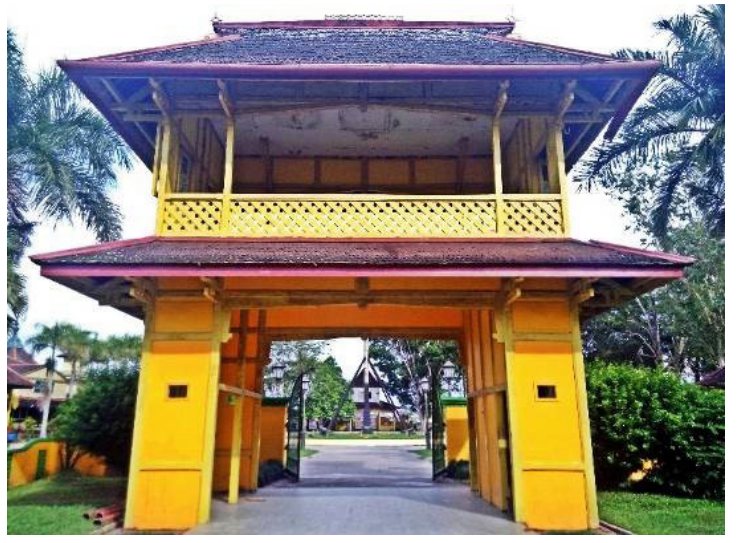

In the second layer of meaning, Pintu Gerbang Dalam works as an index, which suggests the place for the sultan to relax. The gate is only for the royal family/relatives to watch the event/ enjoy the entertainment held in the alon-alon, while the guards are on their posts. In terms of dicentsign, Pintu Gerbang Dalam, shows the impression of closed and open. The impression of being closed can be seen from the presence of the rectangular barriers. The dimension of this gate is $7.14 \mathrm{~m}$ in length, $4.14 \mathrm{~m}$ in width, and $9.97 \mathrm{~m}$ in height. The impression of openness is seen from the empty room in the bottom floor, which functions as the entry and exit point with $4 \mathrm{~m}$ height. In the upper floor there are some openings in the form of window with railing and $1.2 \mathrm{~m}$ height. In terms of sinsign, the unique characteristics of this gate can be seen at its rooftop, which symbolizes the origin of descendants of the Sultanate of Sambas. At the two tips of the rooftop there are two ornaments with the shape of three stars and there is a set of 10 circles at the middle of the rooftop. The three stars represent the three kingdoms from which the Sultanate of Sambas originated. Thus the Sultanate of Sambas inherited three greatest powers prevailing at that time from the Middle Prince, from the Sultanate of Sarawak (Brune), Sepudak Queen, from Majapahit kingdom, and Sulthan Muhammad Tsafiuddin, from Matan Sukadana kingdom. The ten circles represent the number of the generations from the first sultan, Sultan Muhammad Tsafiuddin I (1631 - 1668), up to the tenth generation, Sultan Muhammad Mulia Ibrahim (1931 - 1943).

Figure 21. The private zone and the public zone in the palace. (Source: Researcher, 2018)

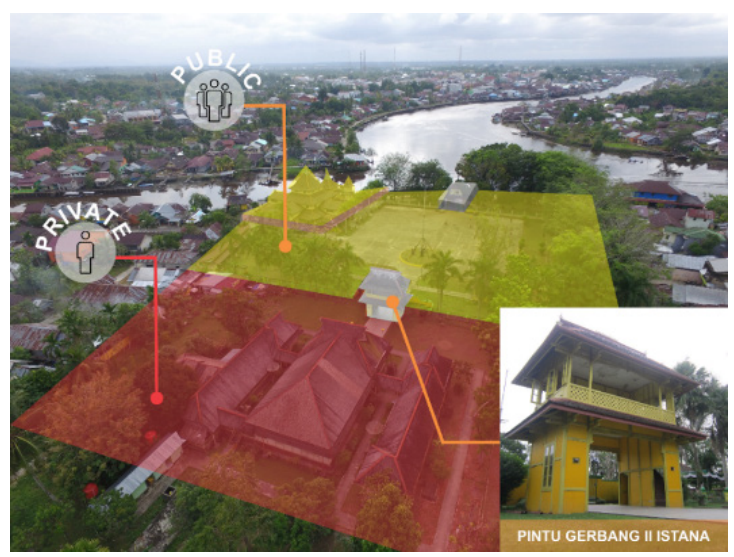

In the third circle of meaning, it works as an icon, representing a watchtower within the palace compound. It is confirmed by Fahmi, who stated that this gate is the main access to the sultanate royal chamber, thus protected with high level of security (interview with Fahmi, 2018). To enable easier surveillance, the guards are posted on the second floor of the gate. The spatial concept of the gate suggests the rheme through the combination of Chinese/oriental and Malay features. The two-floor gate with two-layered roof is the characteristics of the oriental style, particularly Chinese. Such an architectural feature is then combined with Malay culture, resulting in yellow as the dominant color and multiple openings to 
respond to the tropical climate. Based on the image of a city in a territory, Gerbang Dalam Istana conveys the qualisign as the edge or the border with a strong identity (dominated by golden yellow). As the edge, it divides and, at the same time, unites two territories. It also functions to separate the private zone from the public one and, at the same time, unites the two.

Figure 22. The identification of the third circle of meaning in Gerbang Dalam Istana.(Source: Researcher, 2018)

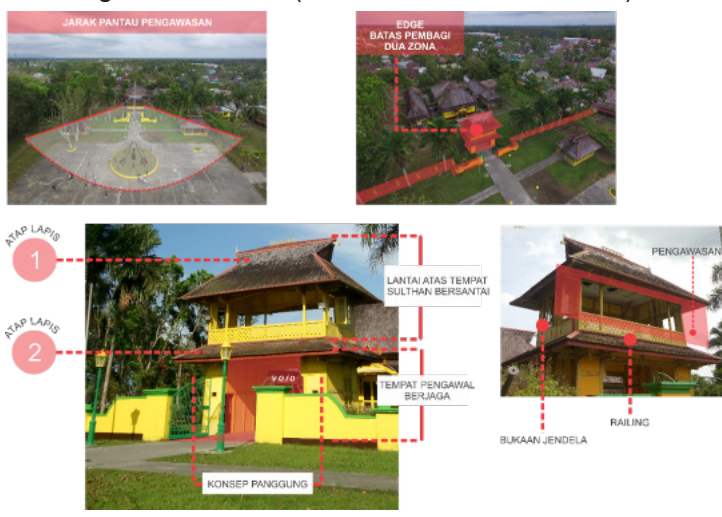

Figure 23. The Circle of Meaning in Pintu Gerbang Dalam (Source: Researcher, 2018)

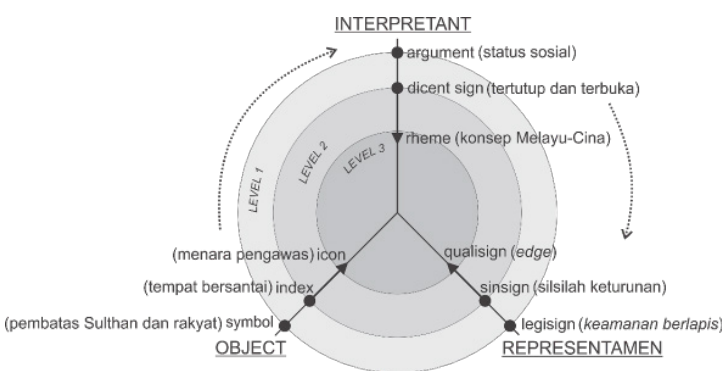

\section{Conclusion}

From the discussion, it can be concluded that, in the context of architecture, the architectural elements conveys the signs which can be classified into each grade of clarity. The unique characteristic of Pierce's theory is the premise that the interpretation of a sign is an unstructured cognitive process. Pierce describes sign as a chain system which continues to develop along with the experience of each observer. Thus, a sign with architectural objects can be analyzed based on the three systems of sign, namely symbol, index, and icon.

The relationship of the grades of clarity is presented in the grades of clarity circle diagram adapted from Theleffsen's diagram. The grades of clarity circle present the sequence of the meanings in such a way so that they can be comprehended more easily. The signs are spread over the compund of Istana Alwatzikhoebillah, namely Kalling Jembatan , Gerbang Segilapan , Alon-Alon Istana, Masjid Jamik Istana, Tiang Kapal Bendere, Paseban , and Pintu Gerbang Dalam, which are positioned along the pathway through which the sultan entered and exited the palace. The different meanings of the five signs constitute a relational relationship as a layered security architecture. The layered security aims to safeguard the departure and arrival pathway of the sultan. The five signs form an interconnected unity.

As the recommendation, the government and administrators are expected to maintain the condition of Jalur Sultan. In the efforts to develop of the palace compound, the five architectural elements should not be altered in order to preserve the meaning they contain. This is to preserve the local wisdom and safeguard the legacy of the ancestors from the royal family of the Islamic Sultanate of Sambas

\section{References}

Akminanti, A. (2013). Simbolisasi Filoso Perusahaan Melalui Logo Pada PT. Pertamina Persero. Jurnal IImu Komunikasi Universitas Mulawarman, 1(1), 87-100.

Broadbent, G. (1980). Sign, Symbol and Architecture. New York: John Wiley \& Sons.

Chandler, D. (2007). Semiotics The Basics (2nd Eed.). USA and Kanada: Routledge.

Dharma, A. (2010). Semotika Dalam Arsitektur. Faculty of Civil Engineering and Planning, Gunadarama University. Retrieved from http://staffsite.gunadarma.ac.id/agus_dh/.

Eco, U. (1976). Teori Semiotika (5th ed.) (I.R. Muzir Trans.). Bantul: Kreasi Wacana.

Fahmi, U.R. (2018). Selayang Pandang Kerajaan Islam Sambas. Dinas Pendidikan dan Kebudayaan Kabupaten Sambas.

Fahmi, U.R. (2018). Personal interview.

Ibrahim, R.A. (2015). Analisa Semiotika Peircian Pada Ruang Perpustakaan Universitas Gadjah Mada (Master's Thesis). Gadjah Mada University, Yogyakarta.

Indrianingrum, L., Azizah, A.N., Prasetya, G.E., \& Hidayah, N. (2015). Pergeseran Peran dan Fungsi Alun - Alun Kaliwungu sebagai Ruang Terbuka Publik. Jurnal Teknik Sipil 
dan Perencanaan, 17(1).

Kamus Besar Bahasa Indonesia Daring (2018). The Ministry of Education and Culture. Retrieved from https://kbbi.kemdikbud. go.id/

Nau, F. (2015, 25 September). Psikologi Warna: Makna Arti Warna dari Segi Emosi. Retrieved from http:// naufalfauzy.blogspot. com/ 2015/09/psikologi-warna-makna-artiwarna.html.

Putra, A.D., Azwir, M., Octaviany, V., \& Nilamsuci, R. (2015). Kajian Transformasi Bentuk dan Fungsi Alun - Alun Bandung sebagai Ruang Terbuka Publik. Jurnal Reka Karsa, 3(3).

Santoso, B.E. (2008). Studi Perencanaan Penataan Kawasan Alun-Alun Kota Brebes. Journal of Civil Engineering, 10(2), 151-160.

Subhan (2017). Personal Interview.

Susilohadi, D.A. (2014). Konsep Perancangan Menara Surabaya sebagai Landmark dalam Fenomena "Iconisation". Journal of Science of Art, 3(2), 2337-3520.

Theleffsen, T. (2000). Firstness and Thirdness Displacement: Epistemology of Pierce's Sign Trichotomies. Denmark: Aalborg University.

Undang-Undang Republik Indonesia Nomor 22 Tahun 2009 tentang Lalu Lintas Dan Angkutan Jalan.

Warpani, P. S. (2011). Alun - Alun. The Department of Urban and Regional Planning, Bandung Institute of Technology. Retrieved from http://tataruang.atr-bpn. go.id/Bulletin/ upload/ data_artikel/edisi5c. pdf). 